\title{
Family, Gender, and Progress: Sophie de Grouchy and Her Exclusion in the Publication of Condorcet's Sketch of Human Progress
}

\section{Sandrine Bergès}

\section{A PHILOSOPHICAL MYSTERY?}

Fearing arrest after his denunciation by the Jacobin Chabot, Nicolas de Condorcet went into hiding in the home of a Madame Vernet, not far from the Luxembourg gardens in Paris. He stayed there from 9 July 1793 until the end of March 1794, a few days before his death. While in hiding, Condorcet started to write an apology (Justification), which was meant to explain and justify his role in the revolution and to show that he had been wronged by his persecutors, the Jacobins. His wife and collaborator, Sophie de Grouchy, sensing that this work would be of little value philosophically or personally, urged him to give it up, and instead to turn back to a work of encyclopedic nature that he had begun several decades earlier: a history of the progress of human nature. This work, divided into ten periods, was to discuss human evolution with a special emphasis on perfectionism, and a

I would like to thank the Bibliothèque de l'Institut in Paris for allowing me to work on the Condorcet and Grouchy papers; colleagues who participated in a work-in-progress seminar where I first presented this paper, Istvan Aranyosi, Sandy Berkovski, Patrick Fessenbecker, Simon Wigley, and Bill Wringe; the audience at the International Association for Women Philosophers conference in Melbourne in July 2016; the editors of the Journal of the History of Ideas; and two anonymous referees. 
running argument on how human progress was affected by freedom and tyranny, science, religion, philosophy, and technology (in particular, the printing press). Rather than attempt to produce the entire work during a time he knew would be limited, Condorcet chose to focus on the introduction, which in his notes he called the Prospectus, but which was published under the title of Esquisse d'un tableau des progrès de l'esprit humain, hereafter Esquisse. ${ }^{1}$ On 25 March, Condorcet left his hiding place for fear of being arrested. He walked for several days until he was arrested in Bourgla-Reine.

The final manuscript of the Prospectus we have is dated October 1793. Condorcet died on 28 March 1794 in a prison cell under an assumed name. When several months later he was identified, the Convention commissioned three thousand copies of his new book, Esquisse d'un tableau des progrès de l'esprit humain. Sophie de Grouchy prepared the edition and it was published in 1795. This edition was reprinted and revised at least twice by Grouchy (alone and with collaborators in 1802 and 1822), and it was translated into English the year it was first published. ${ }^{2}$ In 1847, the Académicien François Arago produced a new edition with extensive revisions, which, he said, was closer to the original manuscript and therefore more accurate. This is the edition that is now regarded as authoritative. ${ }^{3}$

Relating the history of the Esquisse, O. H. Prior called it "a real literary mystery." Noticing that Sophie de Grouchy's editions did not align with the manuscript of the Prospectus that we have, he wondered whether Grouchy, in compiling her editions, referred to a different and now lost manuscript of the Prospectus. Did Arago later have confirmation that the manuscript, which he received from Condorcet's daughter, Eliza O'Connor, and which he housed in the Bibliothèque de l'Institut was the definitive one? Prior added that the only way to solve this mystery would be to figure out who had used which manuscript. ${ }^{4}$ In this paper I argue that the mystery

\footnotetext{
${ }^{1}$ Hereafter, the Prospectus refers to Condorcet's manuscript in MS885 in the Bibliothèque de l'Institut. Esquisse refers to the published versions of that manuscript, the 1795 edition by Grouchy (translated into English the same year) and the 1847 edition by Arago, translated in 1955 by June Barraclough (London: Weidenfeld and Nicolson) and reproduced in Steven Lukes and Nadia Urbinati, Condorcet: Political Writings (Cambridge: Cambridge University Press, 2012). The Tableau refers to the unfinished work for which the Prospectus was intended to be an introduction.

${ }^{2}$ John Adams had a translation printed in London in 1795. Zoltán Haraszti, "John Adams Flays a Philosophe: Annotations on Condorcet's Progress of the Human Mind," The William and Mary Quarterly 7, no. 2 (1950): 223-54.

${ }^{3}$ See Lukes and Urbinati, Condorcet, xiii.

${ }^{4}$ O. H. Prior, ed., "Avertissement," in Condorcet: Esquisse d'un tableau des progrès de l'esprit humain (Paris: Boivin et Cie, 1933), xxiv.
} 
is resolved once we allow for the obvious: Condorcet collaborated with his wife over his last work, as they had done before for many years. After his death she either added text they had discussed, or that she felt, as a collaborator, would be fitting. I argue for this by looking closely at the manuscript that we do have and studying the differences between Grouchy's and Arago's editions. I draw two conclusions: first, at least one passage that appears in the 1795 edition but does not figure in the manuscript makes the work philosophically more interesting; secondly, the fact that no editors or commentators even raise the possibility that Grouchy may have been a coauthor is a sad reminder of the exclusion of female authors from the history of philosophy.

\section{WRITING THE PROSPECTUS}

By the time he moved to Madame Vernet's rooms, Condorcet had already gathered copious notes and materials for his project of a history of human progress. The project was originally planned in nine parts, from the first human tribes through antiquity, the Middle Ages, the Renaissance, Modern times, the Enlightenment, and the Revolution. A note in the margin of a detailed plan indicated that the book would conclude with a reflection on the future progress of mankind. The emphasis throughout would be on those human traits that either impeded or encouraged the natural tendency to perfectionism. On the negative side, Condorcet put religion, ignorance, and tyranny; on the positive, philosophy, science, and technology. An Avertissement would be inserted before the first part and after the Prospectus, summarizing the main lines of the complete work and explaining that the text was not intended as a precise history, but as a presentation of the principal traits of humanity's progress.

Among Condorcet's papers at the Bibliothèque de l'Institut, in a volume catalogued by Arago, his 1847 editor, we find a detailed plan, a complete draft of the Prospectus, fourteen fragments, nine notes, the Avertissement, and a dossier containing references, plans, chronologies, summaries of fragments, and notes, as well as ninety-six shorter notes. ${ }^{5}$ The Avertissement was added to the 1847 edition of the Esquisse by Condorcet's daughter Eliza O'Connor. ${ }^{6}$ Condorcet began to work on this project

\footnotetext{
${ }^{5}$ These are catalogued in Jean-Pierre Schandeler and Pierre Crépel, eds., Tableau historique des progrès de l'esprit humain: Projets, esquisse, fragments et notes (1772-1794) (Paris: Institut National D’Études Démographiques, 2004).

${ }^{6}$ See Schandeler and Crépel, 17.
} 
in the summer of 1793, when he stopped writing his Justification. The final date of the complete manuscript he left is dated 4 October 1793. The manuscript includes a cover page, on rough (wrapping) paper. At the top, three lines read "To the citizen Auguste Cardot, who will give these pages to his brother." In the middle of the page, in a cleaner handwriting, Condorcet wrote: "A la Citoyenne Condorcet." The first three lines, written messily at the top of the page, indicate to whom the manuscript should be delivered. Auguste Cardot's brother had been Condorcet's secretary since 1787 and was still working for him during his time at Madame Vernet's house. Among the notes and fragments, several are copies in his hand. The manuscript was placed in a canvas bag and given to Sarret, Madame Vernet's lodger, for delivery. The second note, written elegantly in the middle of the page, is clearly a dedication to his wife. ${ }^{7}$

One legend surrounding the writing of the Prospectus is that Condorcet wrote it without any notes, relying on his memory of previous research and writings. When Condorcet left his home to go into hiding, he left with nothing that he could not carry discreetly. ${ }^{8}$ This, however, fails to take into account frequent visits he received from his wife, and the fact that she brought him books and notes as he requested them. Condorcet communicated with Grouchy in code, underlining letters in his messages to ask for specific books, or tell her which of the manuscripts he sent had to be copied. ${ }^{9}$ Dressed as a peasant woman, Grouchy would walk in twice a week from the Auteuil gate to the rue des Fossoyeurs, going a different route each time so as not to attract suspicion. ${ }^{10}$ After spending time with her husband, she walked to the little underwear shop she had set up with Auguste Cardot on the rue St Honore and used a studio above the shop to paint the miniatures from which she made a living to support herself, her daughter, and her sister, as well as her old nurse. The walk from Auteuil would have taken over eight hours so it is probable that she sat in a cart with other peasants on their way to sell their goods in the capital. But even the walk from her

\footnotetext{
7 "Pour le Cn Auguste Cardot afin qu'il remette ces pages à son frère," Prospectus. Schandeler and Crépel believe that the manuscript is addressed to be delivered to Sophie de Grouchy and that the note referring to Cardot is a message that she is to pass on to her tenant so he can forward it to his brother. However, the words "A la Citoyenne Condorcet" appear to be a dedication because they are elegantly positioned in the middle of the page, whereas the note to Cardot is scribbled at the top.

${ }^{8}$ See Léon Cahen, Condorcet et la révolution française (Paris: Felix Alcan, 1904), 528.

${ }^{9}$ Schandeler and Crépel, 1121-23.

${ }^{10} 21$ rue des Fossoyeurs is now 15 rue Servandoni. See Antoine Guillois, La marquise de Condorcet: Sa famille, son salon, ses amis, 1764-1822 (Paris: P. Ollendorff, 1897), 137-38.
} 
shop to Madame Vernet's took a long time, as she had to lose herself in the crowds and take various detours so as not to let on that she was visiting her husband. ${ }^{11}$ In January 1794, it was no longer safe to visit, and upon the advice of mutual friends, Grouchy petitioned for a divorce. She continued to correspond with Condorcet, and presumably was able to deliver books and manuscripts via Cardot's brother, who worked with her at the rue St Honoré.

\section{EDITING THE SKETCH}

Almost as soon as Condorcet was declared dead-several months after his actual death, his identification following the discovery of a watch given to him by his brother-in-law-the Convention repented the way he had been treated and decided to honor him by publishing his last work. Pierre Daunou was put in charge of arranging for the printing of three thousand copies of the Prospectus. Although Daunou is often listed alongside (and sometimes instead of) Grouchy as the editor of the 1795 (year III) edition, there is no evidence that he did anything other than arrange for it to be done. In his biography of Daunou, Francois Taillandier lists all the editions Daunou prepared, but does not mention this one, even though he records Daunou's petitioning of the Convention. ${ }^{12}$

The first thing to note, when asking how the Prospectus was edited, is that we do not have a printer's copy-a neat copy where the printer would have made annotations about print setting, etc. Of course these copies were usually destroyed after printing. Yet, had there existed one final copy of the text in Condorcet's hand, one imagines that his wife would have made an effort to recover it from the printer, or perhaps even that she would have preserved it and asked Cardot to make a copy. One does not throw away the last manuscript of one's beloved dead husband. The final copy we do have, the one addressed to Cardot's brother, and dedicated to Grouchy, is far from a neat copy. Parts are crossed out; there are many marginal notes, some of which may be in Grouchy's hand. Clearly, anyone working from this manuscript to produce a book would have had to make a number of decisions that may have affected the content.

The 1795 edition was reprinted, with no significant changes, several times, including in the complete works that Grouchy edited together with

\footnotetext{
${ }^{11}$ See Guillois, 147.

${ }^{12}$ Schandeler and Crépel, 1126n5.
} 
Garat and Cabanis in 1804. This first edition also served for the translation into English that John Adams read and annotated twice, both sympathetically and critically. ${ }^{13}$ But by 1847 , when François Arago, Secrétaire Perpétuel of the Académie (which was the position Condorcet had held from 1773) produced a new complete works, he decided to go back to the original manuscript given to him by Eliza O'Connor. Although we do not know which manuscript that was, we have good reason to suppose that it was the one that is now in the Bibliothèque de l'Institut, as this manuscript was catalogued by Arago himself. We do not know, in any case, of another existing manuscript. According to Arago, the 1795 edition contained several pages that did not figure in the manuscript, and many alterations, so he felt it necessary to go back to a manuscript in Condorcet's own hand. ${ }^{14}$

Indeed, one observes a surprisingly large number of additions and corrections when comparing the first edition to the Institut manuscript. Schandeler and Crépel catalogued 1500 corrections and forty added passages, of which thirty-two are longer than one line and a third are one or more paragraphs long. Alongside the complete manuscript, Condorcet left a number of notes and fragments, which can serve to trace some of the additions and corrections. Some of the additions, however, cannot be wholly accounted for by the notes and fragments. In what follows, I suggest that one particular addition may simply be evidence of Grouchy's own work.

Grouchy was a philosopher in her own right, and at the time Condorcet was writing the Prospectus, she had already completed her Letters on Sympathy, a response to Adam Smith's Theory of Moral Sentiments, in which she drew on Cabanis's physiology (Grouchy and Cabanis collaborated on his work a decade later) and her own theories of republican reform (influenced by the likes of Rousseau and Montesquieu, but very much grounded in her observations of current events). ${ }^{15}$ I have argued elsewhere that Grouchy was the anonymous author and co-author of several articles published in Le Républicain, a revolutionary journal that she ran along with Condorcet, Thomas Paine, and Achilles Duchatellet in the summer $1791 .{ }^{16}$ Grouchy was also a skilled philosophical translator, who produced

\footnotetext{
${ }^{13}$ See Haraszti, 228-29.

${ }^{14}$ Arthur Condorcet O'Connor and Arago, eds., Oeuvres de Condorcet (Paris: Firmin Didot, 1847), below the "Avertissement," xxii.

${ }^{15}$ Marc-André Bernier and Deirdre Dawson, Les "lettres sur la sympathie" (1798) de Sophie de Grouchy: Philosophie morale et réforme sociale (Oxford: Voltaire Foundation, 2010). Note that the letters weren't published until 1798, along with her translation of Smith, when Grouchy needed money.

${ }^{16}$ See Sandrine Bergès, "Sophie de Grouchy on the Cost of Domination in the Letters on Sympathy and Two Anonymous Articles in Le Républicain," The Monist 98 (2015): 102-12.
} 
a translation of Smith's Theory of Moral Sentiments that was still in use in the late twentieth century, and who regularly translated Paine from the English during the revolution. Condorcet, in his Testament to his daughter (written a few weeks before his death) also hints at other pieces by his wife, as he enjoins Eliza to look, when she needs to educate herself morally, to her mother's Letters on Sympathy and that "other writings by her mother give very useful viewpoints on the same subject." ${ }^{17}$ We do not, unfortunately, know what these writings were.

Arago's insistence on using a manuscript in Condorcet's hand (while Condorcet, like many writers, relied on the services of a secretary), suggests that he is casting doubt on the honesty of the editors. And he is not the only one to do so. Charles Coutel, writing about later interpretations (and political recuperations) of Condorcet also criticizes Daunou, claiming that his edition of Condorcet's Plan d'Education is little more than a caricature. Coutel adds in a footnote that the same may be said of Daunou's (he does not mention Grouchy) edition of the Esquisse. ${ }^{18}$ Even the most recent translation of the text into English-reprinted in the 2012 edition by Steven Lukes and Nadia Urbinati-asserts that the 1847 edition should be regarded as the standard, because Arago claimed to have followed the original manuscript. But what Coutel, Arago, Lukes, and Urbinati, fail to take into account when evaluating the 1795 edition (and the nearly identical one reprinted in 1802 in the Condorcet, Barbier, Cabanis, and Garat edition of the works, as well as the one printed together with Condorcet's "Reflexions sur l'esclavage des nègres" in 1822) is that Sophie de Grouchy, Condorcet's widow, was also known to be an editor of that text. ${ }^{19}$ This is significant, as we know that she played an important role in the production of the manuscript that Arago felt compelled to use.

She contributed to the manuscript in several indirect ways: convincing

17 "When the moment of justice has come, she will find help in my writings. The advice I have written for her, and her mother's letters on friendship, will provide a moral education. Other writings by her mother give very useful viewpoints on the same subject." Condorcet, "Condorcet's Testament (March 1794)," in Condorcet: Foundations of Social Choice and Political Theory, ed. Iain McLean and Fiona Hewitt (Aldershot, Hants: Edward Elgar, 1994), 290.

${ }^{18}$ Charles Coutel, "République et instruction publique chez Condorcet," in Fomer un Nouveau Peuple? Pouvoir, éducation, révolution, ed. Josiane Boulad-Ayoub (Québec: Les Presses de l'Université Laval / L'Harmattan, 1996), 13-30.

${ }^{19}$ Mme de Condorcet, Antoine Alexandre Barbier, Pierre Jean Georges Cabanis, and Dominique Joseph Garat, eds., Oeuvres Completes de Condorcet (Brunswick and Paris, 1802). Jean-Antoine-Nicolas Condorcet, Esquisse d'un tableau historique des progrès de l'esprit humain; suivi de réflexions sur l'esclavage des nègres par Condorcet (Paris: Masson et Fils, 1822) [hereafter cited as Esquisse (1822)]. 
Condorcet to abandon his earlier work to write it, bringing him books and notes he may have needed before their apartment and all their possessions were seized, and offering constant moral support and encouragement by visiting and writing. But more importantly, we know that the two worked together, that they were used to exchanging ideas, and that they perhaps collaborated on some pieces. ${ }^{20}$ To this we must add that one annotation in the manuscript, at least, is in Sophie's hand, and that she copied parts of earlier drafts, showing familiarity with the development of the text.

Given that she may have been a part of the creation of the manuscript that Arago used to establish his edition, it seems strange to dismiss the edition that she helped produce based on that same manuscript. At the very least she was familiar enough with Condorcet's writing that she was in the best position to judge what he meant to do with the notes. And if she actually contributed to it, then it would also make sense for her to continue-as a philosopher in her own right and as one of Condorcet's collaboratorsthis work that they had begun together. In the next two sections, I investigate several segments that seem to have been written by Sophie de Grouchy herself.

\section{SEXUAL EQUALITY AND THE PROGRESS OF HUMAN NATURE}

Women are mentioned eight times in the 1795 edition of the Esquisse, but only four times in the Prospectus manuscript, and those mentions, mostly related to the evolution of family life, do little except reinforce ideas of natural inequality, claiming that a mother's affections are stronger than a father's and that women were excluded from the communal decisions of early human gatherings because their physical weakness excluded them from the hunt $(17,18) .{ }^{21}$ In his discussion of the place of theology and philosophy in the dark ages he notes that in Constantinople "some emperors, princes, princesses even" shined in the humanities as well as in theology. ${ }^{22}$ But in his section on the literature of the Middle Ages, he praises the

\footnotetext{
${ }^{20}$ See Bergès, "Sophie de Grouchy on the Cost of Domination."

${ }^{21}$ The in-text page references are to the 1822 edition of the Esquisse, a reprint of the 1795 edition. That the passages in question correspond to the manuscript is verified by Schandeler and Crépel. Translations are mine.

22 "Quelques empereurs, des princes, des princesses même ne se bornèrent point à l'honneur de briller dans les disputes théologiques, et daignèrent cultiver les lettres humaines," Esquisse (1822), 127.
} 
uplifting effect of the values of chivalry that served to help the oppressed and defend the "ladies" ("des dames") (147). In his discussion of the progress of medicine, he emphasizes that studying sexual difference is key to understanding how the human body functions (214).

Not only are there few mentions or discussions of women in the manuscript, there are also gaps in places where one might expect a mention. There is, for instance, no reference to women who contributed to the philosophical and mathematical innovations of antiquity-no mention of Hypatia of Alexandria (114) and no mention of any particular women or of the place of women in general in his discussion of the Pythagoreans. ${ }^{23}$ Gilles Ménage in his Historia mulierum philosopharum (1690) listed twenty female philosophers of antiquity. Condorcet mentions not a single one. Diogenes Laertius names women in Plato's school, the Cynic Hipparchia, the Pythagorean Theano, and the mathematician Hypatia of Alexandria. It seems strange that a thinker who was committed, a few years earlier, to arguing that women were as capable as men intellectually should fail to mention any of these in his survey of intellectual progress. Indeed, Condorcet was not ignorant of the existence of women who had influenced the progress of humanity. In his 1790 pamphlet arguing for the emancipation of women, he lists an impressive number of women who were powerful and had a positive influence in politics, science, and philosophy, including Catharine Macaulay, Marie le Jars de Gournay, and Emilie du Chatelet. ${ }^{24}$ The most charitable interpretation for the absence of women philosophers and scientists from the Prospectus, perhaps, is that they did not come to mind when he was not specifically thinking about them. Whether this was the result of oversight or deliberate omission, the absence of female philosophers in the Prospectus is all the more interesting in light of the feminist element that was added to the text after the manuscript was delivered to Condorcet's secretary. This seems to be evidence of two voices in the text, one more conscious of the need to write about women than the other.

While there are fewer mentions specifically of women in the Prospectus than one might have hoped for from a feminist writer, Condorcet's emphasis on the role of the family in human progress is significant from the point of view of introducing a feminist perspective. On the first page of the first part, "Les Hommes sont réunis en peuplades," Condorcet emphasizes the extent to which human groups are always family based, and how this is grounded in a natural tendency to strong emotional attachments of mothers

\footnotetext{
${ }^{23}$ Fragment 6, in Schandeler and Crépel, 640.
}

${ }^{24}$ Lukes and Urbinati, Condorcet, 157-58. 
and fathers toward their children: "A family society seems to be natural to man. Its origin is to be found in the child's need for its parents and in the natural solicitude of the mother and-though to a lesser extent-of the father for their offspring. But the child's need lasts long enough to bring into existence and foster a desire to perpetuate this life together and to awaken a lively sense of its advantages. A family that lived in a region offering ready means of subsistence could increase and become a tribe." ${ }^{25}$

This may not strike the reader as fundamentally different from what Aristotle says about the origins of the city in book 1 of the Politics: families come first and lead to greater gatherings of people, which then become political societies. But Condorcet's emphasis is on the nature of the family group, on the origins of its existence. Families, Condorcet tells us, come about through a combination of needs and love ("tendresse" in the original). The long-lasting nature of needs deepens the sentiments and leads parents to desire a more permanent togetherness. Family ties were, understandably, a concern of Condorcet's toward the end of his life. In the beginning of "Advice to his daughter," written a few weeks before he died, Condorcet reminds his daughter of his love for her, and the fact that as a baby she was "comforted by [his] loving care." 26

An infant's needs and the love and care it receives are also central premises in Sophie de Grouchy's theory of sympathy. According to Grouchy, our propensity to sympathize with others, and the fact that this propensity has the potential to develop into morality and principles of justice, is closely linked to the first relationships we experience:

This particular dependence on a few individuals begins in the crib; it is the first tie binding us to our fellow creatures. It is the reason why an infant's first smiles, and then her more habitual smiles, are for her nurse, why she cries when she is not in her arms, and why for a long time, she likes to throw herself upon the breast that satisfied her first needs, made her experience her first sensations of pleasure and where she developed and acquired her first habits. ${ }^{27}$

Later on, Grouchy insists on the role of parents as educators, building on those first emotional experiences to develop a child's moral sensibilities.

\footnotetext{
${ }^{25}$ Lukes and Urbinati, Condorcet, 9.

${ }^{26}$ Lukes and Urbinati, Condorcet, 196.

${ }^{27}$ Sophie de Grouchy, Letters On Sympathy, tr. Bergès, ed. Bergès and Eric Schliesser (New York: Oxford University Press, forthcoming), Letter II.
} 
She describes how her own mother taught her to love charity by taking her to visit the poor living on the Grouchy estate as a child.

Condorcet and Grouchy were not, of course, the only republican philosophers of the time to place so much importance on family life. Those who had read and admired Rousseau tended to regard good parenting as one of their first duties as citizens. Wollstonecraft argued that mothers who would not breastfeed their babies did not deserve to be called citizens. ${ }^{28}$ Girondins celebrities Jean-Marie and Marie-Jeanne Roland devised educational programs for their daughter based on Rousseau's Emile and Julie. ${ }^{29}$

While Condorcet does not go on to further discuss how the family develops and influences the progress of humanity, family nonetheless remains central to his argument. In the conclusion of the Esquisse, Condorcet censures the fact that history often overlooks family in favor of the individual: "Until now, political history, as indeed, the history of philosophy and of science has always been the history of a few men. But what the human species actually consists in, the families, subsisting nearly entirely from their labour, has been forgotten." ${ }^{30}$ A history of families, Condorcet concludes, is what we need to study in order to truly understand human progress, as focusing on isolated individuals, exceptionally bred royalty, or heroes, whose paths are exceptional, cannot give us an accurate picture of how humanity in general changed through the ages.

This claim has the potential for being developed into a feminist argument-one of the sort that Susan Moller Okin made in objection to Rawls: families must be central in any account of human development, because they determine in great part how any individual gets to be "who they are." ${ }^{31}$ But families cannot be studied only from the outside, as selfcontained units represented by one (often male) individual, as family dynamics affect the development of individuals. So representing human progress as a succession of changes brought about by individual men leaves out the participation of their family members in bringing about these

\footnotetext{
${ }^{28}$ Mary Wollstonecraft, A Vindication of the Rights of Men; A Vindication of the Rights of Woman; An Historical and Moral View of the French Revolution, ed. Janet Todd (Oxford: Oxford University Press, 1993), 227.

${ }^{29}$ Sian Reynolds, Marriage and Revolution: Monsieur and Madame Roland (Oxford: Oxford University Press, 2012), 75, 94.

30 "Jusqu'ici, l'histoire politique, comme celle de la philosophie et des sciences, n'a été que l'histoire de quelques hommes; ce qui forme véritablement l'espèce humaine, la masse des familles qui subsistent presque en entier de leur travail, a été oubliée," Esquisse (1822), 257-58.

${ }^{31}$ Susan Moller Okin, Justice, Gender, and the Family (New York: Basic Books, 1989), 97.
} 
changes, and in particular, it leaves out the participation of women, who are less often cited as significant actors in history. In order to understand the role played by women in human development, therefore, one must consider the family.

But Condorcet is saying more than that. He suggests that a crucial factor in human evolution is how families interact with each other, and how they interact with new knowledge and technology, which can be traced back to earlier inventions:

The man who tills our soil owes his enjoyment of the commonest goods, which plentifully supply his needs, to the long-continued labours of industry assisted by science; and his enjoyment of these goods can be traced even further back to the victory of Salamis, but for which the shadow of Oriental despotism threatened to engulf the earth. Similarly, the mariner who is preserved from shipwreck by his careful observations of longitude, owes his life to a theory which can be traced back, through a chain of truths, to discoveries made in the school of Plato, and thereafter buried for twenty centuries in total disuse. ${ }^{32}$

But despite the fact that the use of technology derived from scientific and philosophical work is so central to the progress of humanity for Condorcet, and despite the fact that a large part of human daily interactions with this technology is the work of women, in the Prospectus, Condorcet does not argue that we should look at families in order to highlight the role of women or of family groups in human progress. While the argument linking the first part of the Esquisse (which states that family ties are central to human societies) to the conclusion (where it is stated that families must feature in any history of human progress) is missing in the Prospectus manuscript, a passage in the 1795 version edited by Grouchy—one of the passages contested by Arago-bridges that gap, clearly arguing that the reason family life matters to the study of human progress is that it is the best way to study the evolution of gender equality.

The passage in question comprises two paragraphs in the third section, which discusses Greek antiquity:

The habit of a more sedentary life had established, between the sexes, a greater equality. Women were no longer considered simply

\footnotetext{
${ }^{32}$ Lukes and Urbinati, Condorcet, 125.
} 
for their utility, or as slaves that happened to be closer to the master. Men saw in them companions, and at last understood how they could contribute to their happiness. However, even in countries where they were most respected, where polygamy was proscribed, neither reason nor justice was able to bring about a complete reciprocity in duties, rights to separation, or punishments for infidelity. ${ }^{33}$

The author of that paragraph clearly specifies sexual equality as a measure of human progress, that it must be noted in any history of such. The paragraph also draws an analogy between women's relations to their husbands and slaves' to their masters. This is significant as the Prospectus is guided by republican principles, and because Condorcet defines freedom as an opposition to slavery. In Fragment 1, note 2, Condorcet writes, "By a free man we mean one who is not subject in any of his private activities to the arbitrary will of an individual, so that free is opposed to slavery or serfdom, depending on the nature of this subjection, and consequently, to anyone who is subject to the arbitrary will of a despot, a senate, or any other association of individuals" 34

In the light of this understanding of liberty it is meaningful that women are compared to slaves whenever the progress of gender equality is discussed: if women are to achieve liberty equal to men, they must become less and less like slaves, until "complete reciprocity" is achieved. However, the author of the added paragraph notes that women in ancient Greek families were far from achieving such reciprocity, despite the progress that the families did exhibit. The author's take on Greek women is notably devoid of any positive spin-a significant difference between the viewpoint of the 1795 edition and what is observed in Condorcet's notes. To some extent, the passage from the 1795 edition appears to echo a passage in Fragment 6 (the same passage in which, it's worth noting, Condorcet fails to mention women when discussing the Pythagorean schools). Condorcet writes:

\footnotetext{
33 “L'habitude d'une vie plus sédentaire avoit établi entre les deux sexes une plus grande égalité. Les femmes ne furent plus considérées comme un simple objet d'utilité, comme des esclaves seulement plus rapprochées du maitre. L'homme y vit des compagnes, et apprit enfin ce qu'elles pouvoient pour son bonheur. Cependant, même dans les pays où elle furent le plus respectées, où la polygamie fut proscrite, ni la raison ni la justice n'allèrent jusqu'à une entière réciprocité," Esquisse (1822), 37-38.

34 "On appelle libre un homme qui n'est soumis dans aucune de ses actions privées à la volonté arbitraire d'un individu; alors libre s'opposera à esclave, à serf suivant la nature de cet asservissement, et par conséquent à celui qui est soumis à la volonté arbitraire d'un despote, d'un sénat, d'une association quelconque d'autres individus," Schandeler and Crépel, 553-54 [my translation].
} 
"Greek women, although they were confined to domestic and private life, enjoyed a sort of authority inside the family. The laws of the mind and liberty had brought them a little closer to natural equality. They were inferior companions, but their husband's servants. They shared with them the respect of their children and the honour of educating them. If they were excluded from political duties, and even from attending people's assemblies and public games, they shared with men religious duties. They even outdid them in the selling of Oracles." ${ }^{35}$ This passage from Condorcet's notes seems almost like an apology for the Greek's subjugation of women-they were not as harsh as their forebears, Condorcet suggests, and even though women could not leave the home, or participate in politics, they had some authority inside the home. (And that they had religious privileges seems an odd remark in a text that decries the negative influence of religion on human progress!)

It is the second added paragraph that confirms the extent of the difference between Condorcet's original manuscript and the one that was published in 1795:

The history of these struggles, that of the birth, the triumph and the fall of prejudices, will therefore take up a great part of this work, and it will not be the least important or the least useful part. ${ }^{36}$

The author of this passage clearly intends for the discussion of sexual equality to shape the writing of the historical interpretation to come. Condorcet makes it clear in the third part of the Esquisse that the prejudices that initially prevent progress are mostly religious ones (52-56). Here it is suggested that prejudices against women also play a role in slowing down the advances in knowledge and happiness humans are capable of. Although this passage is certainly in line with what Condorcet wrote elsewhere-

\footnotetext{
35 "Les femmes chez les Grecs, quoique soumises à une vie domestique et retirée, jouissaient d'une sorte d'autorité dans l'intérieur des familles. Les lois et l'esprit de liberté les avaient un peu rapprochées de l'égalité naturelle. Elles étaient les compagnes inférieures, mais non les domestiques de leurs maris. Elles partageaient avec eux le respect de leurs enfans et l'honneur de les former. Si elles étaient exclues des fonctions politiques, et même de la presence aux assemblées du peuple et de l'assistance aux jeux publics, elles partageaient avec les hommes les fonctions religieuses. Elles l'emportèrent même dans le talent de vendre des Oracles," Esquisse (1822), 612-14.

36 "L'histoire de ces combats, celle de la naissance, du triomphe et de la chute de prejugés, occupera donc une grande place dans cet ouvrage, et n'en sera pas la partie la moins importante ou la moins utile," Esquisse (1822), 14.
} 
particularly in his 1790 "On Giving Women the Rights of Citizenship"—it is not to be found in any of the notes he left for his Prospectus. ${ }^{37}$ It is fair to assume, therefore, that this particular addition comes to us from his wife and editor, Sophie de Grouchy.

How unusual is this focus on women and family in an analysis of human progress in the late eighteenth century? Certainly Condorcet and Grouchy were not the only writers to look at the conditions of women's lives as a marker of the advancement of civilization. Kathryn Ready argues that a number of eighteenth-century writers did in fact see the status of women as correlated with the advancement of society in general. ${ }^{38}$ One such writer was the German philosopher Christoph Meiners who studied the evolution of women's dress and makeup during war and peace time, arguing for certain correlations. ${ }^{39}$ Another was Marie-Jeanne Roland who in her notes on her journey to England spent time describing women's dress, behavior, and the way in which they interacted with men, and remarked on how this reflected generally on the morals of the English. ${ }^{40}$ But although the practice of using women as markers of progress was not uncommon among writers of history and anthropology, the Condorcet-Grouchy collaboration goes one step further. In the Esquisse, families are not just a showcase for human progress, they are the place where the inventions resulting from scientific discoveries (such as farming tools), for instance, are tested and chosen. By framing the history of human progress with considerations of gender equality, the Condorcet-Grouchy text significantly puts women and families at the center of any discussion of humanity, and sets them up as agents - rather than passive recipients or markers-of progress.

\section{A MYSTERY DIS-SOLVED}

In this discussion of the history of the production of Condorcet's last text, I have tried to show that Arago's and others' dismissal of Sophie de

\footnotetext{
${ }^{37}$ Condorcet, "On Giving Women the Rights of Citizenship. 1790," in Lukes and Urbinati, Condorcet, 156-62.

${ }^{38}$ Kathryn Ready, "The Enlightenment Feminist Project of Lucy Aikin's Epistles on Women (1810)," History of European Ideas 31, no. 4 (2005): 435-50, 440.

${ }^{39}$ Lara Anderson and Heather Merle Benbow, "Christoph Meiners' History of the Female Sex (1788-1800): The orientalisation of Spain and German nationalism," History of European Ideas 35, no. 4 (2009): 433-40, 434.

${ }^{40}$ Marie-Jeanne Roland, "Voyage en Angleterre," in Oeuvres de J. M. Ph. Roland, femme de l'ex-ministre de l'intérieur. . . , tome 3, ed. L. A. Champagneux (Paris: Bidault, An III), 270-75.
} 
Grouchy's 1795 edition and subsequent editions was unfounded for two reasons. First, that as Condorcet's wife and collaborator, and as the philosopher who worked most closely with him during the months when he was writing the Prospectus, we have good reason not to question her authority as to what he might or might not have wanted the final manuscript to look like. Second, that one of the passages she added to the final text-whether she wrote it herself or was inspired by Condorcet's notes or their unrecorded discussions-provide the necessary rationale for Condorcet's conclusion that the history of human progress should focus on families, not individuals. This focus on families is not often recognized or explored: most read it as a philosophy of history which emphasizes human perfectionism through science and philosophy, and therefore one in which the discoveries of a few individuals (often male) matter over and above all else. Condorcet's conclusion is inconsistent with that reading; it is clearly not what he intended, perhaps because he realized that technological innovations, scientific discoveries, and the like have little effect on humanity unless people use them in their daily work and life. The progress of humanity, therefore, is to be measured by the progress of family life. And this, the 1795 editor adds, is to be measured at least partly in terms of equality between men and women.

I hope this paper casts light on Condorcet's text and also serves to illustrate a larger point about the Recovery Project, namely that just as female philosophers of the past found less traditional ways of developing and putting forward their thoughts (novels, letters, translations, etc.), their exclusion from the history of philosophy also took many forms: women have been disregarded not only as authors, but also as editors and collaborators. ${ }^{41}$ Women's contributions will not spontaneously reappear simply because historians no longer display the sort of sexism that was endemic in the past, for their contributions have been systematically erased, not through any particular ill will but for myriad reasons, each in their own way arising from a general culture of male science and erudition, in which women were perceived as helpmates rather than as creative intellectuals in their own right. In order to recover women's contributions, we need to study what Bonnie Smith called the "author-teams that worked in household workshops" ${ }^{42}$-not simply at the text that came out of the print shop,

\footnotetext{
${ }^{41}$ See Bonnie G. Smith's discussion of how historiography needs to perceive that history reflects only the dominant aspects of the truth, i.e. often the male ones, and is not an impartial mirror. The Gender of History: Men, Women, and Historical Practices (Cambridge, MA: Harvard University Press, 1998), 2.

${ }^{42}$ Smith, 57.
} 
but at the process involved in getting it there. The work of the Recovery Project, thus, involves looking at the production history of texts that may have involved women philosophers. This will help us identify work by women that was previously attributed only to men and may enrich, as in the case at hand, our understanding of the works studied.

Bilkent University. 
Copyright of Journal of the History of Ideas is the property of University of Pennsylvania Press and its content may not be copied or emailed to multiple sites or posted to a listserv without the copyright holder's express written permission. However, users may print, download, or email articles for individual use. 